\title{
Development of New World Crops by Indigenous Americans
}

\author{
Jules Janick ${ }^{1}$ \\ Department of Horticulture and Landscape Architecture, Purdue University, 625 Agriculture Mall Drive, \\ West Lafayette, IN 47907-2010
}

\author{
Additional index words. cucurbits, fruits, grains, industrial crops, legumes, nightshades, ornamentals, pseudograins
}

\begin{abstract}
Advanced agricultural and horticultural systems are a feature of pre-Columbian civilizations of the Americas. Practically all of the crops that originated in the New World were domesticated before European incursions. Thus, the New World crops currently grown in Asia, Africa, Europe, and Oceania should be considered as a contribution of indigenous cultures of the Americas to humanity. The history of these indigenous crops can be found in the written post-Columbian record of explorers, correspondents, travelers, and botanists. It can also be traced in the iconographic record derived from pre-Columbian artifacts, illustrated manuscripts, herbals, paintings, and sculpture. This information is particularly useful for such fields as taxonomy, genetics, crop domestication, crop evolution, and genetic diversity. Major New World crops to be reviewed include grains and pseudograins (amaranth, maize, quinoa), legumes (common bean, lima beans, peanut), cucurbits (chayote, pumpkins, squash), solanaceous fruits (capsicum peppers, husk tomato, pepino, tomato), starchy roots and tubers (cassava, potato, sweetpotato), fruit and nuts (blueberry, brambles, cactus pear, cashew, papaya, pineapple, strawberry), beverage crops (cacao, mate), ornamentals (dahlia, fuchsia, sunflower), and industrial crops (cotton, Pará rubber, tobacco).
\end{abstract}

The encounter of America by Christopher Columbus in 1492 was the greatest event of the late Middle Ages and is a convenient benchmark to date the beginning of the Modern Era. During the first two decades after the "discovery" of the Americas, only false hopes were forthcoming. Dyewood, cotton, monkeys, and parrots began to trickle out but the enormous riches alluded to by $\mathrm{Co}-$ lumbus for the ears of his greedy patrons - gold, silver, and jewels - did not materialize. For a score of years, the Spanish confined themselves to a small piece of the Isthmus of Panama and the islands of the Antilles, but riches did not materialize and America was dismissed as another example of Spanish braggadocio. However, on 9 Dec. 1519, the first treasure ship consisting of booty sent by Hernán Cortés, conqueror of Montezuma II, ruler of Tenochtitlan in the Aztec empire, arrived in Spain, and the world was changed forever. It soon became apparent that the New World was not a land of savages but the home of great civilization, including a highly developed agriculture.

Three great cultures coexisted in America, although they were unaware of each other: Aztec, Mayan, and Incan. These were monumental civilizations similar in many respects to that in ancient Egypt with enormous temples in the form of pyramids, pictorial writing, a system of cities and government, a bewildering theology, magnificent art, and a developed agriculture. These cultures also had a dark side-slavery, constant warfare, the offering of living human hearts as sacrifice, and cannibalism. Archaeological evidence indicated

Received for publication 25 Jan. 2013. Accepted for publication $28 \mathrm{Feb} .2013$

This paper was part of the workshop "A Survey on the Contribution of Indigenous People of North America to Horticulture" held 1 Aug. 2012 at the ASHS Conference, Miami, FL, and sponsored by the History of Horticultural Science Working Group (HIST)

${ }^{1}$ To whom reprint requests should be addressed; e-mail janick@purdue.edu. that the New and Old Worlds were once connected through the Bering Strait and Asian peoples migrated to the Americas $\approx 50$ thousand years ago. Ironically, Columbus, in searching for Asia, did discover their descendants.

The gold and silver objects of the New World were melted down to enrich Iberia in the short run, but they were used to finance European wars, which ultimately led to Spain's decline. However, much more valuable than gold and silver treasures were the new crops from the New World that have continually enriched the bounty and cuisine of Europe and the world (Janick, 2011). Important New World crops are presented (Table 1). We review the history and images of New World crops with particular relevance to horticulture.

\section{NEW WORLD CROPS}

\section{Grains and pseudograins}

Various grains and pseudograins were domesticated in the New World, including maize (Zea mays), amaranth (Amaranthus spp.), wild rice (Zizania palustris L.), and quinoa (Chenopodium quinoa). Maize has become the most important world grain, surpassing wheat, rice, sorghum, and millets. World production of maize now exceeds 800 million tonnes with an annual value that surpasses all the gold and silver extracted by the conquistadores. Maize is presently the principal source of animal feed, especially for pigs and chickens, human food (e.g., cornbread, grits, sweet corn, tortillas, and popcorn), as a source of sugars (corn sweetener), and now as a major source of energy (ethanol). The varied uses of corn by man are based on pre-Columbian selection of maize types by indigenous Indians.

Mesoamerica is the center of maize domestication. The transformation of teosinte, bearing approximately a dozen seeds covered in a very hard fruit case that shatters at maturity, into maize, with an ear (pithy condensed inflorescence) that bears hundreds of naked seeds that remain attached to the cob at maturity, is one of the wonders of evolution and plant domestication. Maize was cultivated by Aztec, Mayan, and Incan farmers, and its production and use made settled life and civilization possible. The significance of maize as a major staple among the native people of the New World is evident in the deification of this crop and its popularity as a common feature of ceramic pottery (Fig. 1). The descriptions of maize by Columbus are found in a letter of Peter Martyr d'Anghiera, an Italian teacher connected with the Spanish court, to Cardinal Ascanio Sforza, vice chancellor of the papal court. These and subsequent letters describing the voyages of Columbus were later incorporated in a Latin work entitled De orbe novo (1511). The letter, dated 13 Nov. 1493, specifically mentions maize:

The islanders also easily make bread with a kind of millet, similar to that which exist plenteously amongst the Milanese and Andalusians. The millet is a little more than a palm in length, ending in a point, and is about the thickness of the upper part of a man's arm. The grains are about the form and size of peas. While they are growing, they are white, but become black when ripe. When ground they are whiter than snow. This kind of grain is called maiz.

On 3 May 1494, at the return of some ships from Columbus' second voyage, Peter Martyr delivered seeds to Cardinal Sforza that included maize (Janick and Caneva, 2005). Maize was rapidly planted in Spain, Portugal, Italy, and Turkey and was reported in China in 1555 in the province of Hunan, probably obtained from the Philippines, which was occupied by Spain after Magellan's voyage (Desjardins and McCarthy, 2004).

\section{Legumes}

New World legumes such as common bean, lima bean, and peanut (groundnut) were destined to become important world food crops. The peanut, found in ceramics from the Moche culture in Peru (Fig. 2), was spread 
Table 1. Selected crops indigenous to the New World.

\begin{tabular}{|c|c|c|}
\hline New World crops & Binomial & New World origin \\
\hline \multicolumn{3}{|l|}{ Cereals and pseudocereals } \\
\hline Amaranth & Amaranthus spp. & Mexico \\
\hline Maize & Zea mays & Mesoamerica \\
\hline Quinoa & Chenopodium quinoa & Andean highlands \\
\hline Wild rice & Zizania palustris & Northern North America \\
\hline \multicolumn{3}{|l|}{ Legumes } \\
\hline Common bean & Phaseolus vulgaris & South America \\
\hline Lima bean & Phaseolus lunatus & South America \\
\hline Peanut & Arachis hypogaea & Brazilian-Paraguayan Center \\
\hline \multicolumn{3}{|l|}{ Cucurbits } \\
\hline Chayote & Sechium edule & Mexico, Central America \\
\hline Pumpkin & Cucurbita maxima & South America \\
\hline Squash & Cucurbita moschata, C. pepo & Mexico \\
\hline \multicolumn{3}{|l|}{ Solanaceous fruits } \\
\hline Capsicum peppers & $\begin{array}{l}\text { Capsicum annuum, C. bacattum, } \\
\text { C. chinenese, C. frutescens, } \\
\text { C. pubescens }\end{array}$ & South America, northern Peru \\
\hline $\begin{array}{l}\text { Ground cherry, } \\
\text { husk tomato }\end{array}$ & Physalis peruviana, $P$. philadelphica & Central America \\
\hline Pepino & Solanum muricatum & Tropical America \\
\hline Tomato & Solanum lycopersicum & $\begin{array}{l}\text { Western South America, } \\
\text { domesticated in Mexico }\end{array}$ \\
\hline \multicolumn{3}{|l|}{ Roots and tubers } \\
\hline Cassava & Manihot utilissima & Brazil \\
\hline Potato & Solanum tuberosum & Peru \\
\hline Sweetpotato & Ipomoea batatas & Central America \\
\hline \multicolumn{3}{|l|}{ Fruits and nuts } \\
\hline Annona & Annona cherimola & Brazil \\
\hline Avocado & Persea americana & Mesoamerica \\
\hline Black raspberry & Rubus occidentalis & North America \\
\hline Brazil nut & Bertholletia excelsa & Amazon \\
\hline Blueberry & Vaccinium corymbosum & North America \\
\hline Cacao & Theobroma cacao & Tropical America \\
\hline Cactus & Opuntia ficus-indica & Mexico \\
\hline Cashew & Anacardium esculenta & Brazil \\
\hline Cranberry & Vaccinium macrocarpon & North America \\
\hline Guava & Psidium guajava & Tropical America \\
\hline Jaboticaba & Myrciaria cauliflora & South America \\
\hline Mamey & Mammea americana & $\begin{array}{l}\text { West Indies, northern } \\
\text { South America }\end{array}$ \\
\hline Papaya & Carica papaya & Tropical America \\
\hline Pineapple & Ananas comosus & Tropical South America \\
\hline Pitaya & Stenocereus spp. & Mexico \\
\hline Strawberry & Fragaria chiloensis & $\begin{array}{l}\text { Pacific Coast, North } \\
\text { and South America }\end{array}$ \\
\hline & Fragaria virginiana & Eastern, North America \\
\hline Soursop & Annona muricata & Peru-Ecuador \\
\hline \multicolumn{3}{|l|}{ Industrials } \\
\hline Cotton & Gossypium hirsutum, G. barbadense & Central America, Brazil \\
\hline Quinine & Cinchona calisaya & Peru \\
\hline Rubber & Hevea brasiliensis & Amazon \\
\hline Tobacco & Nicotiana rustica, N. tabacum & Mexico, Central America \\
\hline \multicolumn{3}{|l|}{ Ornamentals } \\
\hline Dahlia & Dahlia spp. & Mesoamerica \\
\hline Fuchsia & Fuchsia triphylla & Hispaniola; South America \\
\hline Helianthus (sunflower) & Helianthus anпuиs & North America \\
\hline Petunia & Petunia spp. & South America \\
\hline
\end{tabular}

worldwide by European traders and became particularly important in Africa after being brought there from Brazil. Phaseolus bean was vital to New World agriculture for agronomic, nutritional, and culinary reasons. Beans and maize were sown in the same hole and the two crops complemented each other. Maize acted as a support for the climbing beans, and nitrogen-fixing bean as a result of rhizobium bacteria provided this element to the soil. Furthermore, maize and beans complement each other nutritionally to form a complete protein: maize seed is deficient in the essential amino acid lysine and bean seed is deficient in the sulfur-containing amino acids, cysteine and methionine. The mixture of beans and tortillas (maize pancakes) provide a complete protein food that was the basis of Aztec and Mayan diets. It remains the basis of Mexican cuisine to this day.

\section{Cucurbits}

The New World cucurbits, Cucurbita moschata, C. pepo, C. maxima (squashes and pumpkins), and Sechium edule (chayote), were important crops of the indigenous population and were grown for their fruit and seed. Representation of $C$. pepo can be found in Incan ceramic pottery (Fig. 3). The first representation of this cucurbit in Europe is a painting of $C$. pepo subsp. texana (Paris et al., 2006) found in an illustrated prayer book, Horae ad usum romanum (Les Grandes Heures), painted for Anne de Bretagne, twice Queen of France, by Jean Bourdichon (14571521) between 1503 and 1508. The image bears the Latin name Colloqui[n]tida and the French name Quegourdes de turquie. The festoons on the ceiling in the Villa Farnesina in the Loggia of Cupid and Psyche also contain various examples of C. maxima (both gray and white pumpkins) and C. pepo (pumpkin type and small gourds) (Fig. 4). The New World cucurbits became prominent in $\mathrm{Re}$ naissance herbals in the 16th century and the genre known as natura morta (still life) popular in the 17th and 18th century; many can be found on the Purdue University New Crops web site under Iconograph-Plant Image (<http://www.hort.purdue.edu/newcrop/ iconography/default.html $>$ ).

New World cucurbits can be also found in the portraits of Arcimboldo (Fig. 5). Chayote, a minor New World cucurbit, can be found in the Mixtec Selden Codex, 1556, and we know it reached Spain soon after because it is found in a famous painting by Juan Sánchez Cotán dating to the early 1600 s (Fig. 6) (Janick and González Reimers, 2009).

\section{Solanaceous fruit crops}

Capsicum peppers and pepino, important food crops with ceremonial and medicinal uses in pre-Columbian America, are represented in various indigenous ceramics (Fig. 7). Because Columbus was looking for black pepper, the discovery of the even more pungent fruits of various species of Capsicum led to their immediate acceptance and popularity throughout the world, particularly in Asia and China where they became an important part of their cuisine. European herbal images of capsicum pepper are abundant and sculpted forms can be found on the door of the Pisa Cathedral (Italy) along with tomato (Fig. 8). Interestingly, except for one dubious image based on a spinning whorl (McMeekin, 1992), no clear pre-Columbian images of tomato have been found. An early painting of tomato (Fig. 9) in Fuchs' unpublished Vienna Codex painted between 1549 and 1556 by Albrecht Meyer was only published in 2001. Tomato fruit, because of its resemblance to the poisonous Old World mandrake, was treated with skepticism but soon was consumed raw and cooked to become an integral part of Italian cuisine, and now 


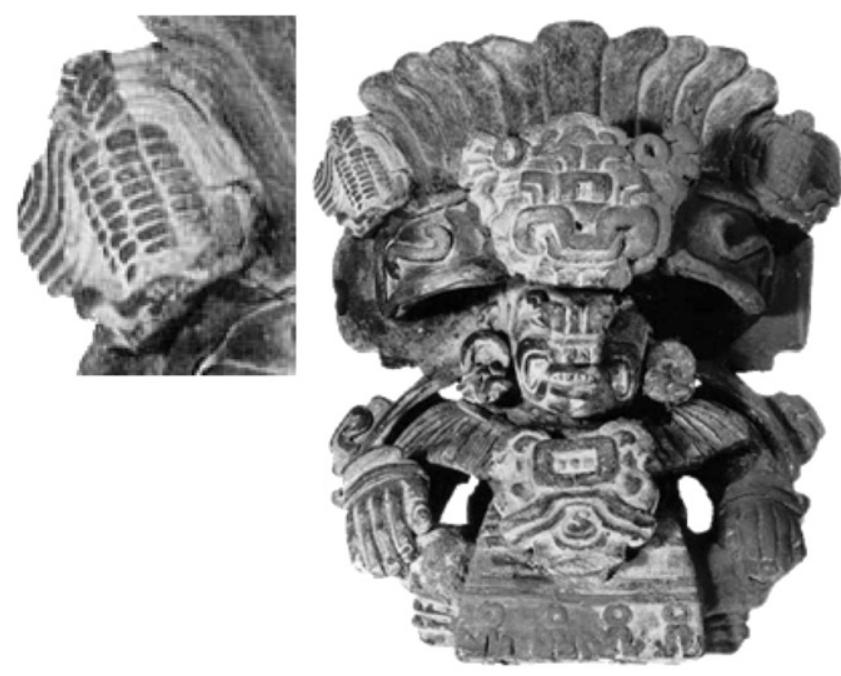

Fig. 1. Zapotec corn god and ear of corn; extrusion from ear resembles tassel ear mutant.

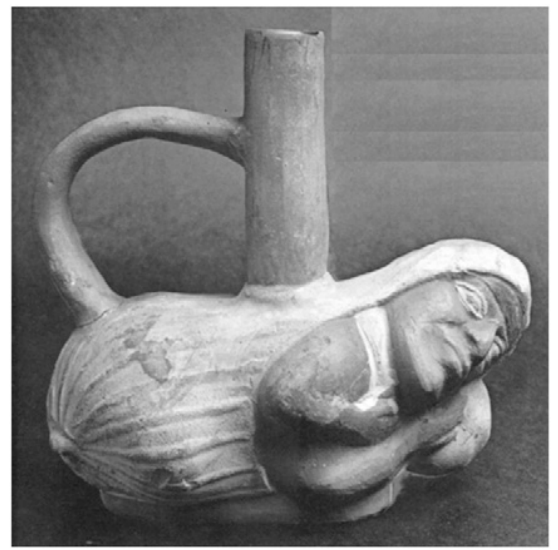

Fig. 2. Peruvian ceramic of peanut. Source: Leonard (1973).
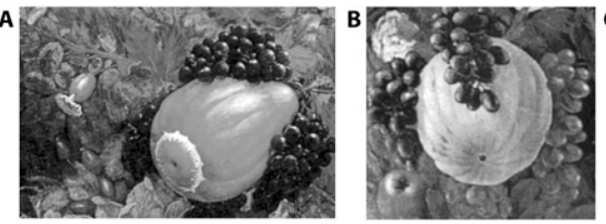

Fig. 4. New world cucurbits on the ceiling of the Villa Farnesina, 1515-1518: (A-B) pumpkin, Cucurbita maxima; (C) squash and gourds, C. pepo. Source: Janick and Paris (2006).

is one of the most important fresh and processed world vegetables.

\section{Root and tuber crops}

Indigenous people in the New World domesticated a number of starchy vegetables, including cassava, potato, and sweetpotato, that have become very important world crops. There are numerous images of potato in preColumbian sculpture (Fig. 10), and potato
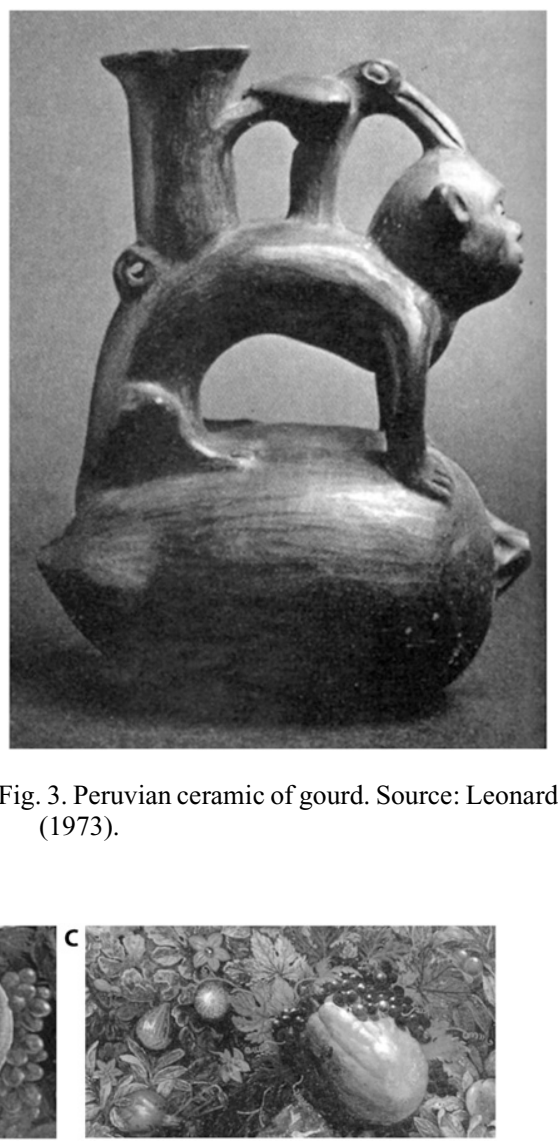

Fig. 3. Peruvian ceramic of gourd. Source: Leonard (1973).

culture of the Incas is illustrated in a calendar presented to the King of Spain in 1580 (Fig. 11). The first printed illustration of potato in Europe is from the famous English 1597 Herball of John Gerard(e) (Gerarde, 1597; Fig. 12). An earlier and more beautiful image is the watercolor received by Clusius in 1589 (Daunay et al., 2008). Potato has become one of the 10 most important world food crops.

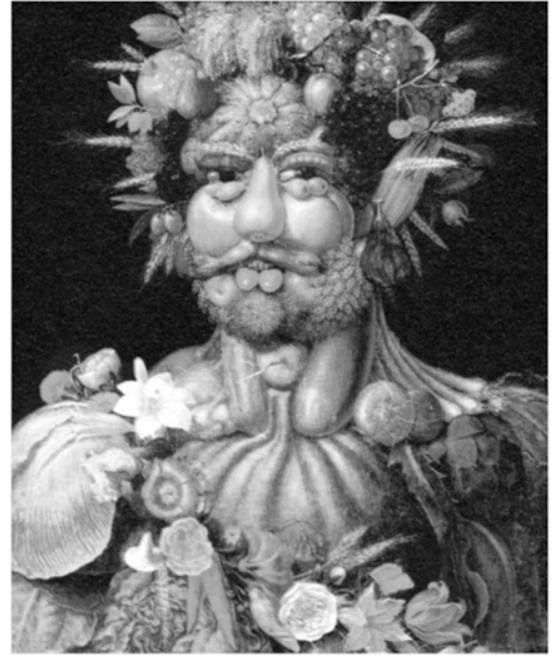

Fig. 5. Pumpkin as chest in portrait of Rudolf II as Vertumnus by Giuseppe Arcimboldo, 1590; note also maize as "ears."

\section{Fruit crops}

There are various temperate, subtropical, and tropical fruits in the New World that have become valuable world crops and many such as various annonas, guava, jaboticaba, and mamey that are still not fully used. The most important will be treated here.

Blueberry/huckleberry. Various North American native ericaceous genera, including Vaccinium and Gaylussacia, were widely used by indigenous tribes. They were especially combined with dried meat in a product called pemmican. This topic will be treated more fully in a companion article by Kim Hummer (2013) in this volume.

Brambles. Rubus species are abundantly found across North America with the blackberry (Rubus subg. Rubus), red raspberry, and black raspberry ( $R$. idaeus and $R$. occidentalis, respectively) being the most well known and most important commercially. There is no evidence that native peoples did any cultivation of these crops, although some burning of forests to open up the canopy for these crops to thrive, as was done for Vaccinium sp., may have been done. Nearly all commercial blackberry cultivars grown for the fresh and processed industry were developed from species native to North America. Similarly, the black raspberry cultivars that are commercially grown were developed from the species native to much of eastern North America. The red raspberry, $R$. idaeus, is native circumboreally and most of the cultivated raspberries were developed in Europe before being brought to North America by early settlers.

Cacao. The seeds of cacao originating in the Amazon Basin were long prized in Mesoamerica and the seeds once used as currency by the Aztecs; the fruits are a common feature in pre-Columbian pottery (Fig. 13). Ground fermented cocoa bean is the main source of chocolate. The pulp surrounding the seed is delicious and remains to be commercially exploited. The beverage xocolatl, 


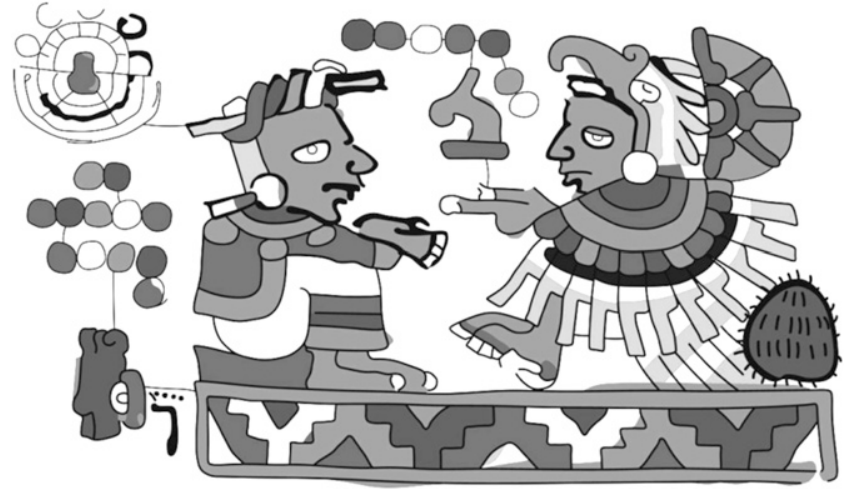

Fig. 6. Chayote (lower right) redrawn from Selden Codex, 1556. Source: courtesy of Fernando Moreira.
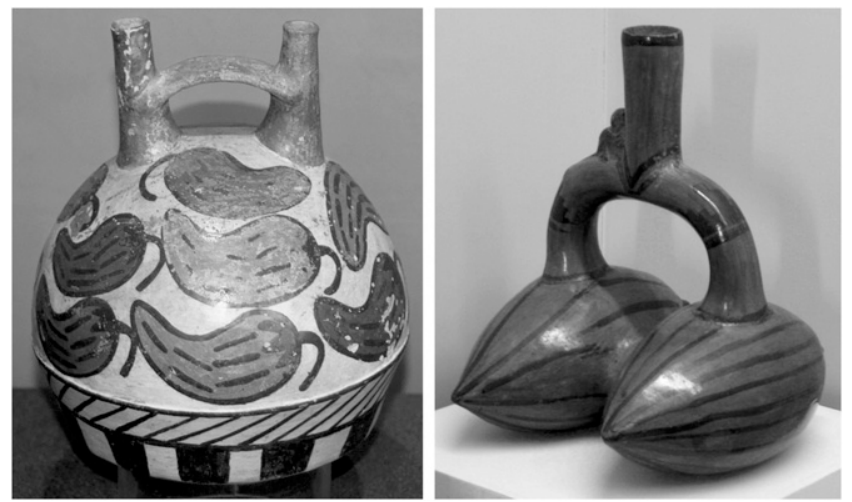

Fig. 7. Pre-Columbian ceramic images of pepper (left) and pepino (right).
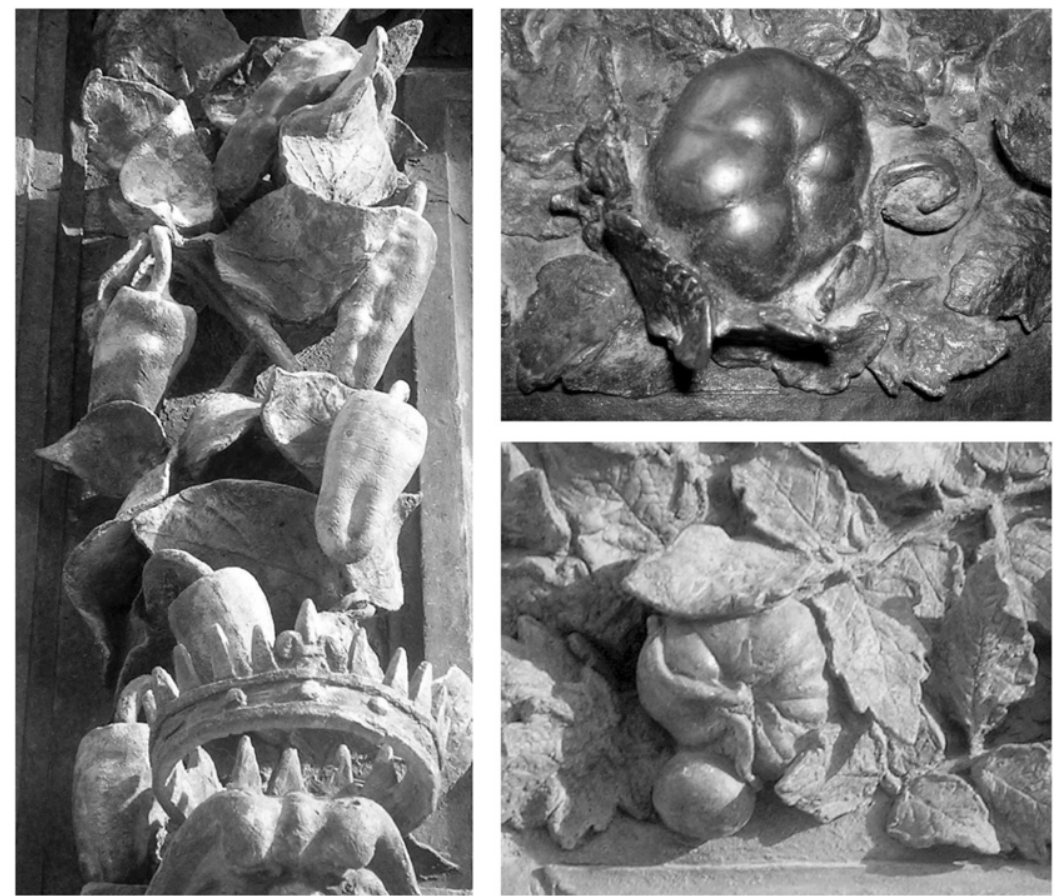

Fig. 8. Capsicum pepper (left) and tomato (right) on the door of the Pisa Cathedral, 1601. Photograph by Jules Janick.

a Nahuatl word meaning bitter water, was introduced to the Spanish court in 1544 and soon became very popular in Europe when the hot chili flavoring was replaced with sugar.
Cactus fruits. The cactus family (Cactaceae) is confined to the New World but has been distributed worldwide. Cacti (Fig. 14) have become important world crops for fruit

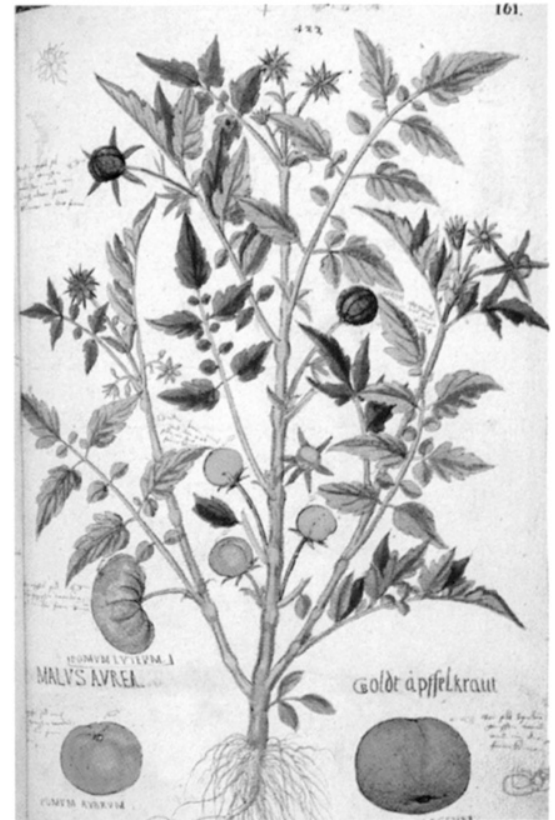

Fig. 9. Herbal images of tomato from Fuch's Vienna Codex (1549-56). Source: Daunay et al. (2008).

(cactus pear, pitaya), vegetables (cladodes), animal feed, and ornamentals. Cactus is also a source of a red dye known as cochineal obtained from the bodies of a parasitic scale insect (Dactylopius coccus).

Pineapple. Columbus in his second voyage of 1493 found domesticated pineapple on the island of Guadeloupe, an island in the eastern Caribbean, and described it as piña de India because of its resemblance to a pinecone. Antonio Pigafetta, who accompanied (and completed) Ferdinand Magellan in his circumnavigation voyage of the earth, described it exuberantly in 1519: "this fruit resembles a pine cone and is extremely sweet and savoury; in fact is it the most exqusite fruit in existence." The fruit was introduced to Africa and reached southern India by 1550 and by the end of the 16th century had reached the Philippines, Java, and China. The first illustration and description in 1535 in the La historia general y natural de las Indias by the Spanish historian Gonzalo Fernandez de Oviedo y Valdes (known commonly as Oviedo) shows a fruit similar to present-day cultivars (Fig. 15).

Papaya. This tropical fruit is now ubiquitous as a backyard tree in the tropics worldwide and has become an important export in Brazil, Hawaii, Mexico, and Thailand. A papaya plant (Fig. 16) can be seen in the drawing dated to the end of the 16th century of an Indian planting seed with the aid of a digging stick in a wattle-enclosed garden found in an anonymous manuscript entitled Histoire Naturelle des Indes, now known as the Drake Manuscript in the Pierpont Morgan Library (Janick, 2012). The amateurish but spirited illustration titled in French, The manner and style of gardening and planting of the Indians, by an unknown French Huguenot 

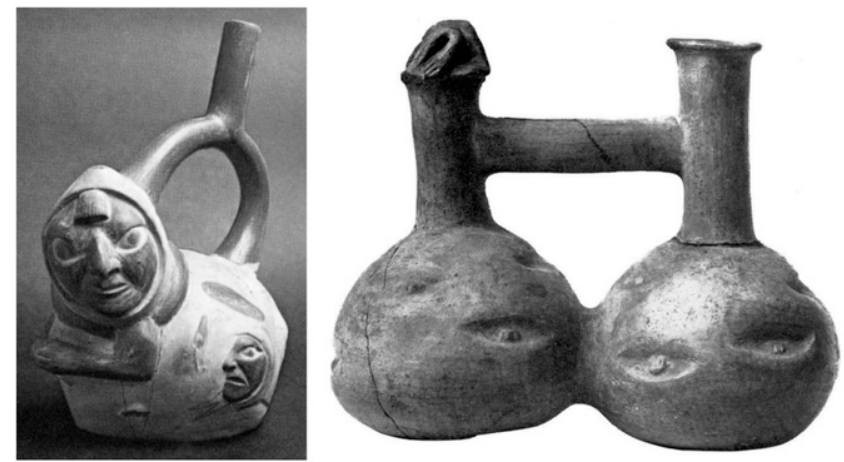

Fig. 10. Pre-Columbian ceramics of anthropomorphized potato. Source: Leonard (1973) and Salaman (1949).
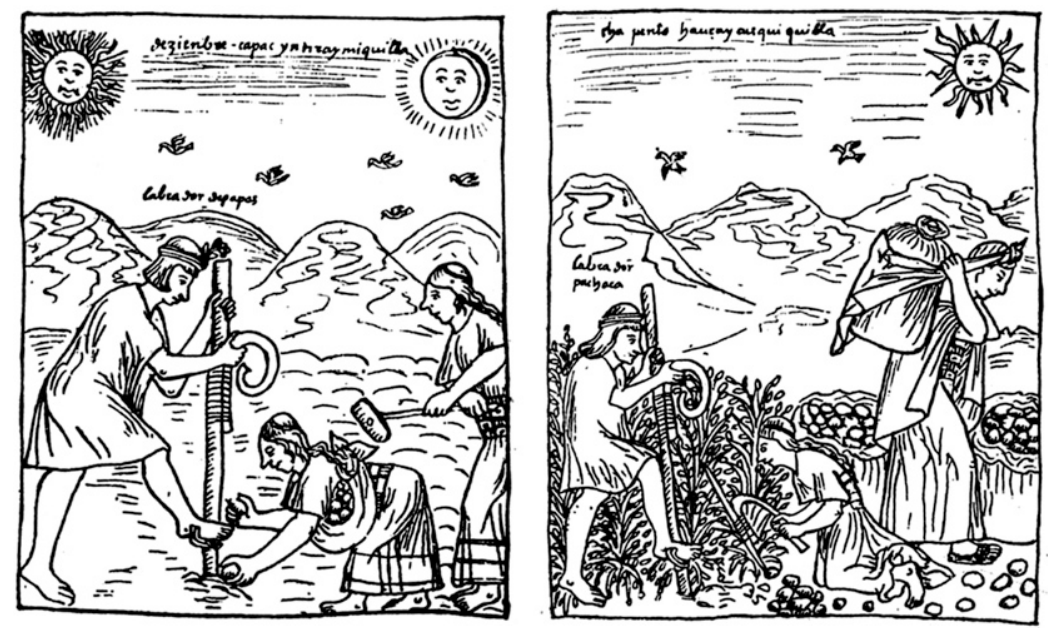

Fig. 11. Planting (left) and harvesting (right) of potato by the Incas, 1589. Source: Leonard (1973).

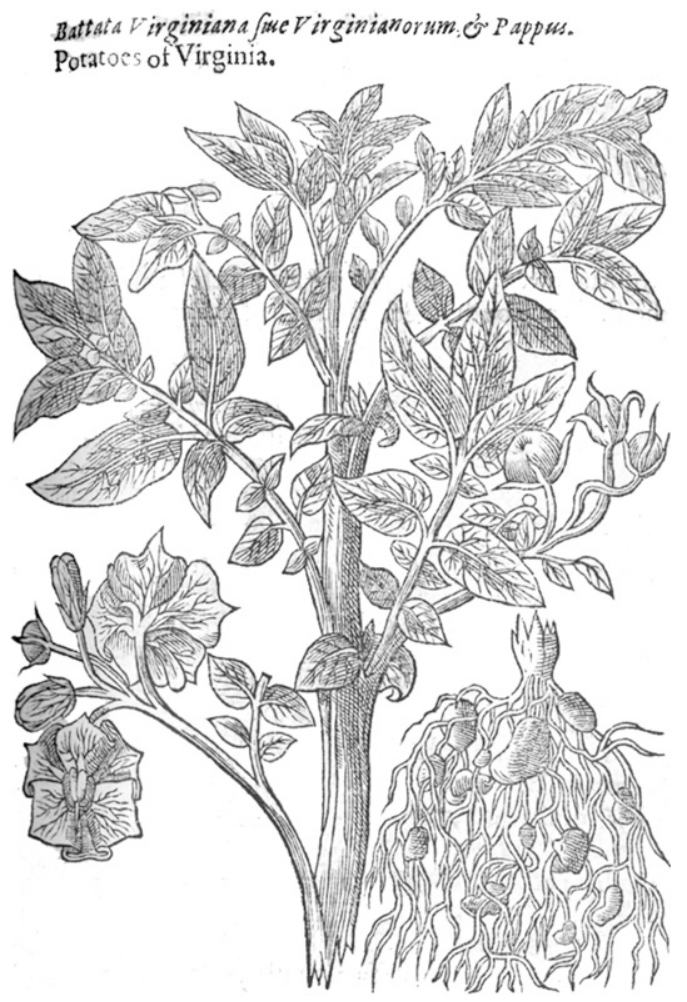

Fig. 12. The first illustration of potato in the Herball of John Gerarde (1597). sailor, also shows multieared maize, a cucurbit vine (probably C. moschata) bearing many large round fruits, two bean plants climbing poles, capsicum pepper, and a pineapple.

Strawberry. The small-fruited diploid Fragaria vesca $(2 n=2 x=14)$ was well known in Europe but the modern largefruited octoploid strawberry $(2 n=8 x=56)$ is derived from $F$. chiloensis and $F$. virginiana that hybridized in France. Large whitefruited forms of $F$. chiloensis were found growing in Chile by Amédee François Frézier, army officer and spy, whose name curiously derived from the French word (fraise) for strawberry, with $F$. virginiana native to the St. Lawrence River, Canada. The pistillate plants of $F$. chiloensis were sent to the King's Garden in Paris but did not bear fruit the first year but eventually intercrossed with the octoploid $F$. virginiana and gave rise to the modern strawberry, $F$. Xananassa (Darrow, 1966). This will be discussed in more detail in a companion article in this volume (Finn et al., 2013).

\section{Ornamentals}

The Americas have been the source of over 1000 garden plants (Taylor, 2009). Various ornamentals including dahlia, fuchsia, helianthus, and petunia have become very important in floriculture and are now grown worldwide. Helianthus, the sunflower, has long been associated with America as a food and medicinal plant and became an important ornamental and oilseed crop in the 20th century. Associated with the sun, they were long known as Flos Solis Peruvianus although native to North America. The first European illustration of sunflower is found in an herbal of Rembert Dodoens (1568), Florum, et Coronariarum, and soon sunflower became an ever-present symbol in European art (Fig. 17). The iconic portraits of sunflower by Vincent Van Gogh have become some of the highest priced paintings.

\section{Industrial crops}

Four New World crops, cotton (Gossypium), Pará rubber (Hevea brasiliensis), tobacco (Nicotiana spp.), and quinine (extracted from Cinchona sp.), exploited by indigenous Americans were to have important effects on world history. American cotton, derived from two species of Gossypium, $G$. hirsutum from Central America and G. barbadense from Brazil, accounts for the majority of world cotton production as a result of its longer, stronger fibers compared with Old World cottons. By a strange twist of fate, a strain of long staple American cotton is now generally referred to as Egyptian cotton.

The resinous latex from the tropical Amazonian tree $H$. brasiliensis is used for the production of rubber, which has important uses in transportation, clothing, and the electrical industry. Rubber has become one of the most vital industrial crops, but the industry is now concentrated in Southeast Asia, particularly Malaysia. 

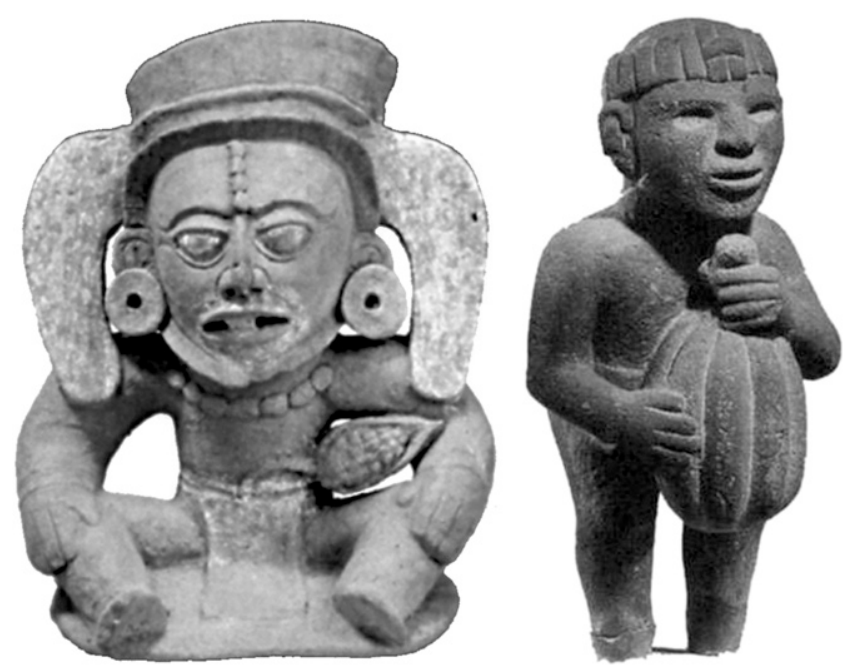

Fig. 13. Pre-Columbian ceramics of cacao.
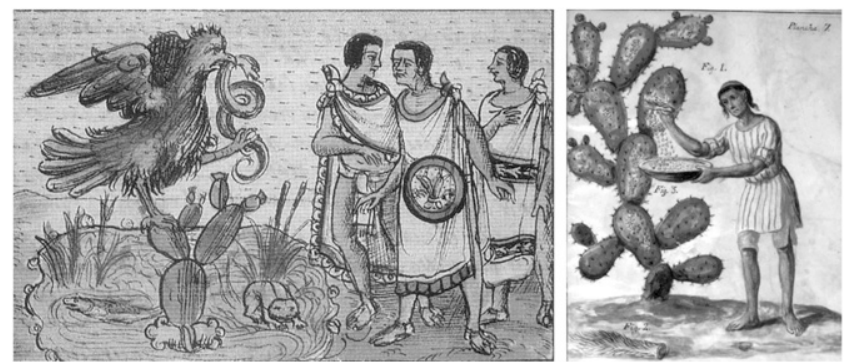

Fig. 14. Early images of cactus pear: (left) an iconic Aztec image that has become the symbol of Mexico; (right) harvesting cochineal from cactus. Source: Inglese (2009)

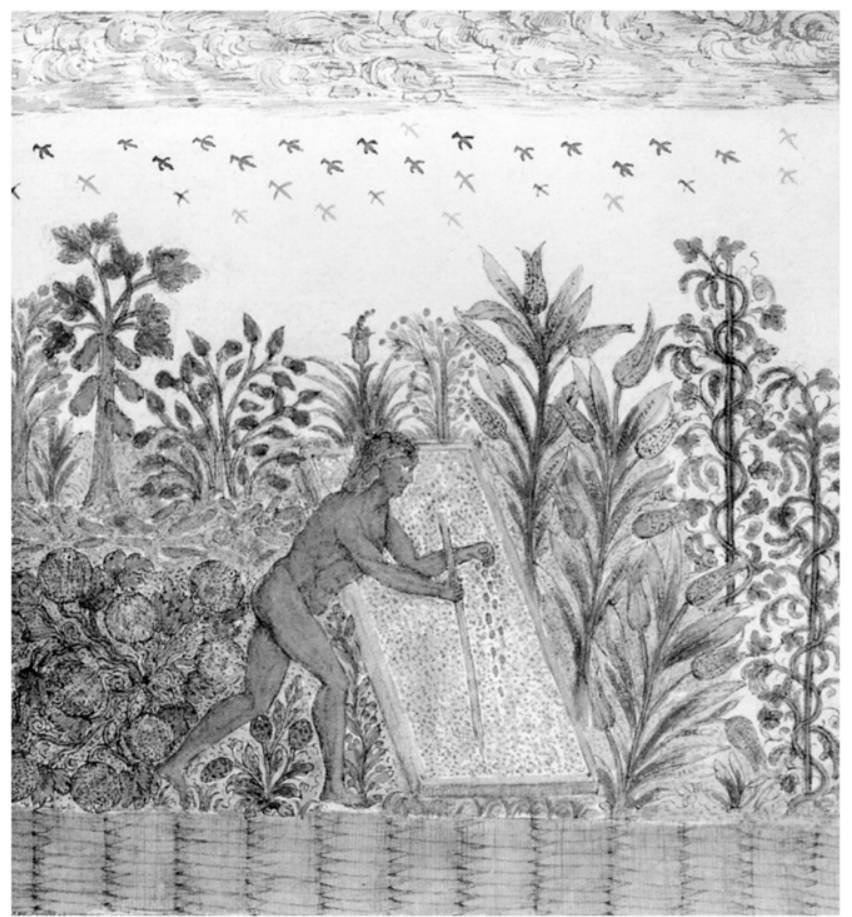

Fig. 16. An Indian garden from Histoire Naturelle des Indes, known as the Drake Manuscript, by an anonymous Frenchman at the end of the 16th century shows papaya, pineapple, maize, beans, and cucurbits.

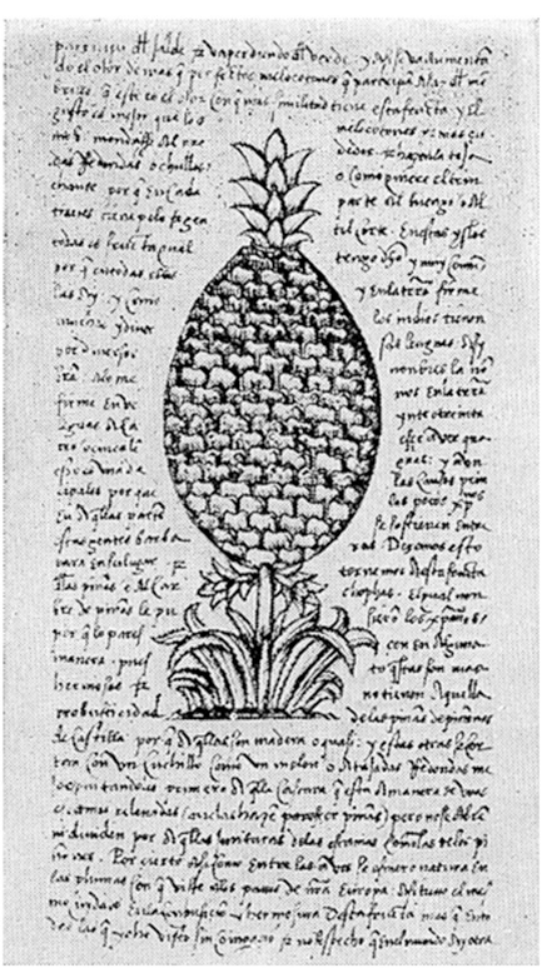

Fig. 15. The first illustration and description of pineapple from Oviedo's Historia, 1526, shows modern-type fruit.

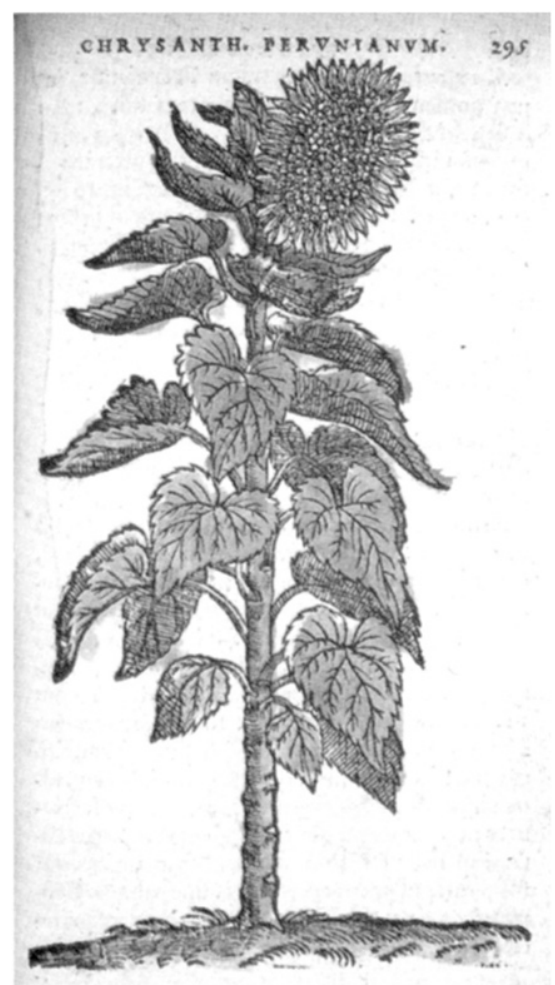

Fig. 17. The first sunflower image from Dodoens: Florum, et Coronaraium, 1568. Source: Mancoff (2001). 

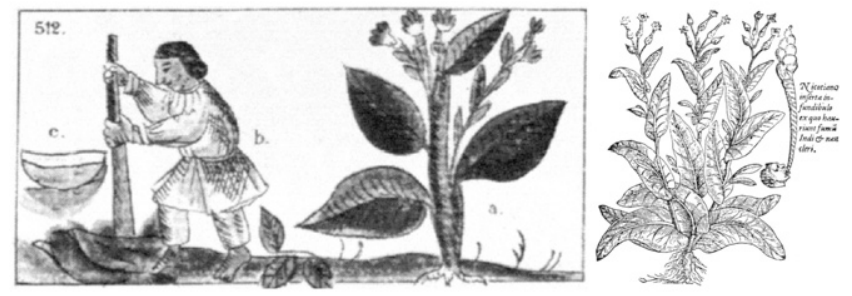

Fig. 18. Tobacco: (left) grinding leaves of tobacco plant from the Florentine Codex 1540-86; (right) Nicotiana tabacum from L'Obel Nova stirpium adversaria; note head smoking tobacco on the right.

Tobacco is widely found in Mayan images (Robicsek et al., 1978). Tobacco, produced mainly from N. tabacum and N. rustica, was domesticated by indigenous Americans and was widely smoked, chewed, or snuffed for medicinal and possibly hallucinogenic purposes in a complex system of rituals (Fig. 18). The use of tobacco was quickly adopted by Europeans to become a worldwide habit as a result of the psychotropic effects of the alkaloid nicotine. Originally considered a panacea, tobacco is now considered to be one of the most dangerous drugs as a result of its severe health effects, but it is still legal in all countries but Bhutan, where production and sale have been outlawed.

The drug quinine, derived from the cinchona tree known to Quechuan healers of Peru, was one of the first truly efficacious drugs because it directly destroyed the protozoan associated with malaria; it is now superseded by other drugs. It is still consumed as the bitter ingredient of certain soft drinks known as quinine or tonic water and is the basis for the popular cocktail gin and tonic.

\section{CONCLUSIONS}

This brief review of New World crop plants is meant to underscore the contributions of indigenous Americans to plant domestication. Three conclusions are evident: 1) the high degree of development of many domesticated American crops at the time of the European encounter; 2) the advanced state of agricultural practices of pre-Columbian culture in the New World; and 3) the modern importance of many of these crops to world agriculture, cuisine, and industry. The New World crops currently grown in Asia, Africa, Europe, and Oceania should be considered as a gift to humanity by the native peoples of the Americas.

\section{Literature Cited}

Darrow, G.M. 1966. The strawberry: History, breeding and physiology. Holt, Rinehart and Winston, New York, NY.

Daunay, M.-C., H. Laterrot, and J. Janick. 2008. Iconography and history of Solanaceae: Antiquity to the 17th century. Hort. Rev. 34:1-111+ 31 plates.

Desjardins, A.E. and S.A. McCarthy. 2004. Milho, makka, and yu mai: Early journeys of Zea mays to Asia. 29 Mar. 2013. <http://www.nal.

Dodoens, R. 1568. Florum, et coronariarum odoratarumque nonnularum herbarum historia... Ex officina Christophori Plantaini, Antverpiae.

Finn, C.E., J.B. Retamales, G.A. Lobos, and J.F. Hancock. 2013. The Chilean strawberry (Fragaria usda.gov/research/maize/>. chiloensis): Over 1000 years of domestication. HortScience 48:418-421.

Gerarde, G. 1597. The herball or generall historie of plants. John Norton, London, UK.

Hummer, K. 2013. Manna in winter: Indigenous Americans, huckleberries, and blueberries. HortScience 48:413-417.

Inglese, P. 2009. Cactus pear: Gift of the New World. Chron. Hort. 49:15-19.

Janick, J. 2011. New World crops: Iconography and history. Acta Hort. 916:93-104.

Janick, J. 2012. Revelations from Histoire Naturelle des Indes known as the Drake Manuscript: Horticulture and history. Chron. Hort. 52:1422.

Janick, J. and G. Caneva. 2005. The first images of maize in Europe. Maydica 50:71-80.

Janick, J. and A.L. González Reimers. 2009. Juan Sánchez Cotán: Mystical artist of horticulture. Chron. Hort. 49:6-8.

Janick, J. and H.S. Paris. 2006. The cucurbit images (1515-1518) of the Villa Farnesina, Rome. Ann. Bot. (Lond.) 97:165-176.

Leonard, J.N. 1973. First farmers. Time Life Books, New York, NY.

Mancoff, D.N. 2001. Sunflowers. Art Institute of Chicago, Thames \& Hudson, New York, NY.

McMeekin, D. 1992. Representations of preColumbian spindle whorls of the floral and fruit structure of economic plants. Econ. Bot. 46:171-180

Paris, H.S., M.-C. Daunay, M. Pitrat, and J. Janick. 2006. First known image of Cucurbita in Europe, 1503-1508. Ann. Bot. (Lond.) 98:4147.

Robicsek, F., M.D. Coe, and B.A. Goodnight. 1978. Smoking gods: Tobacco in Maya art, history, and religion. Univ. Oklahoma Press, Oklahoma City, OK.

Salaman, R. 1949. The history and social influence of the potato. Cambridge Univ. Press, Cambridge, UK.

Taylor, J.M. 2009. The global migrations of ornamental plants: How the world got into your garden. Missouri Botanical Garden Press, St. Louis, MO 